\title{
Mantle-Derived Diatremes in the Southern Green River Basin, Wyoming, USA
}

\author{
Hausel, W.D. ${ }^{1}$, Kucera,R.E. ${ }^{2}$, McCandless, T.E. ${ }^{3}$, and Gregory, R.W.1
}

1. Geological Survey of Wyoming, Box 3008 University Station, Laramie, Wyoming, 82071, USA

2. Guardian Reources Ltd., 355 Burrard Street, Vancouver, B.C., V6C 2G8, Canada

3. Center for Mineral Resources, Department of Geosciences, University of Arizona, Tucson, Arizona, 85721, USA

A group of igneous bodies with mafic to ultramafic affinity was recently discovered in the vicinity of Cedar Mountain in the southern Green River Basin of southwestern Wyoming in the western United States. The diatremes cluster at the southern margin of a $2500 \mathrm{~km}^{2}$ anomalous region containing detrital mantle-derived 'kimberlitic' indicator minerals. These minerals are found in ant mounds and adjacent soils in Wyoming, in the Bishop Conglomerate (Oligiocene?) in Wyoming and Colorado, and in stream sediment samples along the northern flank of the Uinta Mountains in northern Utah. The significance of this anomaly was first recognized by McCandless (1982) who identified the mineral grains as mantle-derived minerals of possible kimberlitic origin. The source of the detrital indicator mineral anomalies in eluded researchers until the discovery of 11 cryptovolcanic igneous bodies along the southwestern flank of Cedar Mountain near the Utah border by R.E. Kucera.

The breccia diatremes and dikes occur near Cedar Mountain, along a north-south, 10-20 kilometer lineament in the Bridger Formation (Eocene), and lie along a regional trend defined by the Leucite Hills lamproites to the northeast, and the Francis lamproites to the southwest. The Cedar Mountain diatremes are on the southern margin of the Green River Basin, a topographic and structural basin filled with Cretaceous and Tertiary sedimentary rocks that cover the southern margin of the Archaean Wyoming Craton. The largest diatreme in the group, the DK pipe, measures 130 by 250 meters and is a greenish-grey breccia with abundant lithic sedimentary fragments from underlying strata. Additionally, the breccias contain crystalline basement xenoliths, mantle-derived eclogite nodules, and kimberlitic indicator minerals.

Geophysical surveys over the DK diatreme showed the breccia to be conductive; however, the clayrich Bridger Formation country rock yielded higher conductivity than the pipe breccia resulting in a relative conductivity low. Magnetic surveys yielded weak, positive anomalies. Another potential breccia pipe was identified by geophysics 12 kilometers northeast of the Cedar Mountain diatremes in late 1997. Reconnaissance magnetic surveys in this region have detected several circular to irregular and elongate anomalies (Guardian Resources, Press Release, Nov. 25, 1997).

Selected breccia matrix samples yielded $67.66-44.08 \% \mathrm{SiO}_{2}, 0.47-0.27 \% \mathrm{TiO}_{2}, 9.86-5.25 \% \mathrm{Al}_{2} \mathrm{O}_{3}$, 5.13-2.82\% $\mathrm{Fe}_{2} \mathrm{O}_{3}, 0.22-0.04 \% \mathrm{MnO}, 14.95-4.29 \% \mathrm{MgO}, 17.99-5.10 \% \mathrm{CaO}, 1.75-0.57 \% \mathrm{Na}_{2} \mathrm{O}$, 2.49-1.41\% K2O, 0.56-0.22\% $\mathrm{P}_{2} \mathrm{O}_{5}, 17.77-6.6 \% \mathrm{LOI}, 0.14-0.07 \% \mathrm{Cr}_{2} \mathrm{O}_{3}$, and 755-256 ppm Ni, and $5.44 \% \mathrm{CO}_{2}$. The $\mathrm{MgO}$ content is low and the $\mathrm{SiO}_{2}$ content is high compared to average kimberlite, and the chemistry also does not appear to be comparable to lamproite. However, the $\mathrm{Ni}$ and $\mathrm{Cr}$ signatures suggest contribution from a mafic to ultramafic source. Back-scatter microprobe analysis completed at the University of Washington on the rock matrix shows cryptocrystalline silica. The matrix contains no identifiable magmatic component and may be the result of a gas-solid mixture which disrupted the overlying Bridger Formation (Tony Irving, pers. comm., 1996). Possibly, these cryptovolcanic structures represent disrupted sediments overlying mafic to ultramafic diatremes at depth.

Indicator minerals recovered from the Cedar Mountain diatremes and dikes include garnets, pyroxenes and oxides, along with some mini-xenoliths similar to those found in nearby anthills (McCandless and Nash, 1996). Both peridotitic and eclogitic garnets occur in the mineral assemblage. Microprobe analyses indicate the garnet suite includes peridotitic garnets with 
dominantly calcic G9 pyrope compositions, and eclogitic pyrope-almandine garnets with low sodium $\left(\leq 0.06\right.$ wt. \% $\mathrm{Na}_{2} \mathrm{O}$ ) content. All but one pyroxene from this suite yielded $\mathrm{K}_{2} \mathrm{O}<0.07 \%$. The exception was a calcic chromian diopside of peridotitic paragenesis that yielded $0.10 \% \mathrm{~K}_{2} \mathrm{O}$ suggesting probable origin within the diamond cogenetic field. Ilmenites yielded 4.8-7.0 wt.\% MgO, and $0.0-4.5 \mathrm{wt} . \% \mathrm{Cr}_{2} \mathrm{O}_{3}$ typical of kimberlitic ilmenites (the compositions suggest favorable conditions for diamond preservation). Chrome spinels yielded 14.5-57.0 wt.\% $\mathrm{Cr}_{2} \mathrm{O}_{3}$ and 0.0-19.7 wt.\% $\mathrm{MgO}$.

Thirteen garnet-pyroxene mini-xenoliths recovered from the DK pipe contained garnets with high almandine content suggesting a granulite (lower crustal) source. Four other xenoliths yielded magnesian pyrope-almandine (Group II) garnets of probable eclogitic origin. None of the garnets contained elevated $\mathrm{Na}_{2} \mathrm{O}$ which suggests they originated at depths too shallow for diamond stability. McCandless and Nash (1996) determined that omphacite/pyrope-almandine intergrowths found in the anthills originated at depths of 40-60 kilometers, and chrome pyrope/chrome diopside pairs originated at depths of 50-90 kilometers.

There are, however, unverified reports of diamonds found in the region. These include 5 diamonds rumored to have been found by a diamond exploration company in the early 1980s. Four diamonds were also reportedly found in the Butcherknife Draw area to the north several years ago (Paul and Jean Miller, pers. comm., 1994). The Butcherknife Draw area lies within the area with abundant kimberlitic indicator mineral-bearing ant mounds. One of the diamonds was cut in Germany and mounted in a ring. The stone measures 0.3 inch across and was confirmed as diamond by a gemmologist using a GEM diamond tester (Wayne Sutherland, pers. comm., 1995).

The diatreme indicator mineral suite is nearly identical to the regional detrital suite, which also includes chromian diopside, chromian enstatite, pyrope garnet, pyrope-almandine garnet, ilmenite, chromite, and salitic pyroxene (McCandless et al., 1995). Extensive drainage sampling in the Uinta Mountains to the south produced only a few indicator mineral anomalies, and no continuous mineral trains could be established between the Green River Basin and the Uinta Mountains. In addition, salitic diopsides found in the Bishop Conglomerate were not found in the samples from the Uinta Mountains (McCandless et al., 1995). Thus, the diatremes are interpreted as the source of at least some of the detrital indicator minerals in the area. However, the widespread distribution of indicator minerals in this region suggests the presence of dozens of similar, undiscovered diatremes.

\section{References}

McCallum, M.E., and Mabarak, C.B., 1976, Diamond in State-Line kimberlite diatremes, Albany County, Wyoming, Larimer County, Colorado: Geological Survey of Wyoming, Report of Investigations $12,36 \mathrm{p}$.

McCandless, T.E., 1982, The mineralogy, morphology, and chemistry of detrital minerals of a kimberlitic and eclogitic nature, Green River Basin, Wyoming: M.S. thesis, University of Utah, S.L.C., Utah, 107 p.

McCandless, T.E. and Nash, W.P., 1996. Detrital mantle indicator minerals in southwestern Wyoming, USA: evaluation of mantle environment, igneous host, and diamond exploration significance: Exploration and Mining Geology, 5, p.33-44.

McCandless, T.E., Nash, W.P., and Hausel, W.D., 1995, Mantle indicator minerals in ant mounds and conglomerates of the southern Green River Basin, Wyoming in Jones, R.W., ed., Resources of southwestern Wyoming, Wyoming Geological Association 1995 Field Conference Guidebook, p. 153-163. 